preventive and curative health responses needs to be reconsidered. Development of immediate health strategies, policies, and interventions are the most important of the present day and this development has to move ahead from promises to practices. The gap between healthcare professionals and the patients must be narrowed if optimal results are to be achieved. This may result in the change of perception and the development of trust in medication that will lead to ideal pharmaceutical care.

\section{Fahad Saleem,}

PhD candidate, Discipline of Social and Administrative Pharmacy, School of

Pharmaceutical Sciences,

Universiti Sains Malaysia.

E-mail: fahaduob@gmail.com

\section{Mohamed Azmi Ahmad Hassali,} Senior Lecturer/HOD, Discipline of Social and Administrative Pharmacy, School of Pharmaceutical Sciences,

Universiti Sains Malaysia.

\section{Asrul Akmal Shafie,}

Senior Lecturer, Discipline of Social and Administrative Pharmacy, School of

Pharmaceutical Sciences,

Universiti Sains Malaysia.

\section{REFERENCES}

1. Benson J, Britten N. Patients' decisions about whether or not to take antihypertensive drugs: qualitative study. BMJ 2002; 325(7369): 873-876.

2. Britten N. Patients' ideas about medicines: a qualitative study in a general practice population. $\mathrm{Br} J \mathrm{Gen}$ Pract 1994; 44(387): 465-468.

3. Bichmann W. Primary health care and traditional medicine - considering the background of changing health care concepts in Africa. Soc Sci Med Med Anthropol 1979; 13B(3): 175-182.

4. Edwards SD. Traditional and modern medicine in South Africa: a research study. Soc Sci Med 1986; 22(11): 1273-1276.

DOI: 10.3399/bjgp10X515467

\section{Revalidation}

In the double speak of Big Brother, Mike Pringle and Steve Field hold the banner of revalidation like Custer at the last stand.

David Edgcumbe has clarified what most hardworking conscientious GPs have known for years. When it comes to revalidation there is little support from College Members and fewer from outside the College. ${ }^{1}$ I raised this at Council 2 years ago, but College Council packed with GPs who do not feel the heat of wallto-wall consultations have no realisation that the Emperor has no clothes.

Quality general practice has no room for performing like a circus clown every 5 years. Despite all the platitudes that it is about professional development, it is about measuring what we cannot measure and removing GPs who do not tick the boxes.

As a UK GP abroad, I see the barriers being erected to prevent UK GPs returning from New Zealand or Australia which will cement the loss of UK doctors. To require GPs, who in my experience are more competent than those in the UK, to jump these hurdles will ensure that they stay abroad.

Let us vote and see if the Emperor really does have clothes.

\section{David Stephens,}

Waihi, New Zealand.

E-mail: david.stephens2@nhs.net

\section{REFERENCE}

1. Edgcumbe D. Let's take a vote on revalidation. $\mathrm{Br} \mathrm{J}$ Gen Pract 2010; 60(576): 537.

DOI: 10.3399/bjgp10X515476

\section{New competencies ignored: general practice is in danger in Italy}

As The European Academy of Teachers in General Practice and Family Medicine specifies, GP trainees have to be trained in the specific competencies this profession requires. These competencies have been defined on the grounds of the traditional expectations of GPs but are in need of evaluation, revision, and directed development for the immediate future of general practice.

According to Nigel de KareSilver, ${ }^{1}$ there are a range of new competencies that require the advocacy of general practice within the medical profession: leadership, representation in society, academic and journalistic writing, teaching of students, trainees, and doctors from other specialties, advising professional bodies, both governmental and scientific, and research.

Currently, in Italy very little is taken in to account of this new skill set when recruiting or training graduates, nor at the undergraduate level where we are only at the first step in creating courses with a core general practice curriculum in a few centres in Milan and Rome. Some big and underfunded changes are on the horizon in the reorganisation of delivery of health care. These would strongly impact on the social role of the GP. ${ }^{2}$

Established GPs are extremely frustrated at being pulled and pushed by politicians and technologists with big and unrealistic decisions in the form of diktat.

In Italy there is a serious danger that GPs, so nationally divided with no effective lobby, would be 'changed' into a new breed of clinician, little more than bureaucratic officers or clerks, becoming a new group in which the holistic relational core competencies will be lost before new ones are learned and applied. ${ }^{3}$ In Italy there is no flexible scheme to provide protected time for teaching, research, or leadership. As a consequence, social needs will receive little consideration and GPs will perform only low-level duties, be subservient to local health politicians, and eventually progressively escape from family medicine, resulting in falling GP numbers from the loss of established doctors through retirement that will not be replaced due to the falling number of GP trainees.

\section{Francesco Carelli,}

Professor of Family Medicine, University of Milan. E-mail: carfra@tin.it

\section{REFERENCES}

1. De Kare-Silver N. Training for change. Br J Gen Pract 2010; 60(576): 542-543.

2. IMF External Relations Department. International Monetary Fund. IMF Executive Board Concludes 2009 Article IV Consultaion with the United Kingdom. http://www.imf.org/external/np/sec/pn/2009/pn0984.ht 